\title{
Development of carp fish culture practice under different stocking densities in mid hills of Uttarakhand, India
}

\author{
K.S. Mehta ${ }^{1}$, Akansha Khati ${ }^{*}$, Mohd Danish ${ }^{2}$, V.K. Singh ${ }^{3}$ and H.C.S. Bisht ${ }^{4}$ \\ ${ }^{1}$ Afro Asian Development Consortium, New Delhi, INDIA \\ ${ }^{2}$ Department of Fishery Biology, College of Fisheries, G. B. P.U.A\&T, Pantnagar-263149 Uttarakhand), INDIA \\ 3Krishi Vigyan Kendra, Lohaghat-262524 (Uttarakhand), INDIA \\ ${ }^{4}$ DSB Campus, Kumaun University, Nainital -263002 (Uttarakhand), INDIA \\ *Corresponding author. E-mail: akanshakhati@gmail.com
}

Received: June 19, 2015; Revised received: January 18, 2016; Accepted: May 17,2016

\begin{abstract}
The present study was undertaken in order to standardise the stocking density values of carps fishes for sustainable fisheries development in mid hills and enhancing the fish production. The paper deals with growth performance of 3 exotic fish species in low stocking density i.e. $3 \mathrm{fish} / \mathrm{m}^{3}$ over high stocking density of 5 fish $/ \mathrm{m}^{3}$ and $10 \mathrm{fish} / \mathrm{m}^{3}$ in the control pond. The net production was $12.6 \%$ higher with stocking density of $3 \mathrm{fish} / \mathrm{m}^{3}$. Among the both tested density, the combination of 30: 40: 30 was superior (45.6\%) in terms of growth and production in comparison to the other combinations and control. In present study, the highest production as $57.13 \mathrm{~kg} / 100 \mathrm{~m}^{2}(5713$ $\mathrm{kg} / \mathrm{ha}$.) was achieved in the stocking ratio of $30: 40: 30$ with stocking density of $3 \mathrm{fish} / \mathrm{m}^{3}$. It is $4.7 \%$ higher of the combination of $40: 30: 30$ and $4 \%$ higher than the combination of $30: 30: 40$. It is $12.6 \%$ higher than the stocking density of $5 \mathrm{fish} / \mathrm{m}^{3}$ and $48.5 \%$ higher than the stocking density of $10 \mathrm{fish} / \mathrm{m}^{3}$. The growth pattern reflected the slow growth during the winter months, reflected the direct negative effect of water temperature on the growth. The production level of existing practice of the farmers may be enhanced up to 1.5 times with proper stocking density i.e. $3 \mathrm{fish} / \mathrm{m}^{3}$ and perfect species combination i.e. 30: 40: 30 for silver carp, grass carp and common carp respectively.
\end{abstract}

Keywords: Carps, Growth performance, Mid-hills, Stocking density, Stocking ratio

\section{INTRODUCTION}

Uttarakhand hills are endowed with rich water resources such as rivers, rivulets, springs, lakes, pond/ tanks etc. (Mahanta and Sarma, 2010). The low productivity and higher degree of resource seasonality and unpredictability in this region gives rise to a unique diversity of aquatic life which is usually prone to many types of disturbances (Bhatt et al., 2012; Jena and Gopalakrishnan, 2012; Singh et al. 2014). These water bodies have rich diversity of fish fauna comprising mahseer, snowtrout, Labeo dyocheilus, Labeo dero, Trout, Channa sps., Machrobrachium sps. Exotic carps etc. (Chandrasekharan et al., 2005; Mahanta and Ayyapan, 2007).

Fisheries play an important role in the socio-economic life of the people dwelling in the mountainous zones. The majority of dependents on fish as means of livelihood are now facing problems to meet their both ends owing to sharp decline in fish catch in the upland areas. Keeping in view the squeezing land burgeoning human ratio, mountain fish resources base is of great relevance and development of such areas becomes matter of national concern, which needs different technological approach and support services. Such regions have to be tapped for increased fish production for national basket and rural development in hills. Culture of native fishes such as mahseer, Schizothorax etc. have not been found economically promising since their poor growth, thereby it takes 3-4 years to grow as marketable size in tanks/ponds (Singh, 2007; Tripathi, 2007). Stocking two or more complimentary fish species can increase the maximum standing crop of a pond by allowing a wide range of available food items and the pond volume to be utilized (Hassan, 2011). Therefore, the farmers are doing culture of silver carp, grass carp and common carp with limited success and is primarily due to lack of development of proper package of practice for carp farming suitable for this area. Farmers are presently doing carp farming on hit and trial basis. Therefore, in present study attempts has been made to develop package of practices for effective carp farming suitable for mid-hills of Uttarakhand.The rate of fish growth is dependent on a number of factors including species, age, genetic potential, water temperature, health, and quantity and quality of food. Young fish are capable of doubling their weight in a much shorter time than when they are older due to a decrease in potential growth rates (Alyshbaev 2013, Kefi et al., 2014). 


\section{MATERIALS AND METHODS}

The experiment was carried out for a period of 12 months in seven rectangular ponds $\left(\mathrm{T}_{\mathrm{I}}-\mathrm{T}_{7}\right)$ at research station, Lohaghat district Champawat. All the experimental ponds were well prepared before the stocking and limed @ $4 \mathrm{~kg} / 100 \mathrm{~m}^{3}$, manured with raw cow dung (a) $30 \mathrm{~kg} / 100 \mathrm{~m}^{3}$ and filled with clean water. All six ponds were considered as six treatments and were labelled as T1, T2, T3,T4,T5 and T6. One treatment (Pond) of control (C) was also maintained in order for proper validation of the trial. The experiment was set up under polyculture system of carps in three different combinations (silver carp, grass carp and common carp 40: 30:30, 30: 40: 30 and 30:30:40) with two densities $\left(3\right.$ and $5 \mathrm{fish} / \mathrm{m}^{3}$ ). In control, the density was 10 fish/ $\mathrm{m}^{3}$ with combination of 25: 25: 50 of silver carp, grass carp and common carp, respectively (Table 1). The density and combination of species in control was taken similar to the existing practice of the farmers of study area. Fishes were fed twice a day with a diet inclusive of $30 \%$ crude protein at a rate of $3.5 \%$ body weight. The fish samples were weighed and measured at the time of stocking and thereafter at every fortnight ten fish samples of each species were captured through drag net. They were weighed and measured with the help of electronic balance and measuring scale and released back in their respective ponds. Average survival and average growth rate was calculated by taking in to account of total as well as initial readings of the concerned parameter.

\section{RESULTS AND DISCUSSION}

In the present study, an attempt has been made to evaluate the production performance of different 3 exotic carp species (silver carp, grass carp and common carp) under polyculture system of carps in 3 different combinations (silver carp, grass carp and common carp 40:30:30, 30:40: 30 and 30:30:40) and with 2 densities ( 3 and $5 \mathrm{fish} / \mathrm{m}^{3}$ ). In control, the density was $10 \mathrm{fish} / \mathrm{m}^{3}$ with combination of $25: 25: 50$ of silver carp, grass carp and common carp, respectively (Table 1). In the upland waters the Indian major carps do not grow well, due to the low thermal regime. Therefore, Chinese carps were taken as the candidate species for polyculture. Three species of exotic carps at density of 2.8-4 fish $/ \mathrm{m}^{3}$ were also taken for polyculture (Tyagi and Joshi, 2009) and it was found suitable for the culture in mid hills conditions similar to present study. The growth rate and average final weight of different species in different experimental ponds are presented (Table 3). Results of trial were compared with the control having the stocking rate and species combination in accordance of existing practiced in the region. At the time of stocking the average weight of fish was $13.13 \mathrm{~g}, 11.38 \mathrm{~g}$ and $7.67 \mathrm{~g}$ for silver carp, grass carp and common carp, respectively (Table 2). Presently, farmers are following the stocking of fry sized fish; therefore size of the fry $1.49 \mathrm{~g}, 1.34 \mathrm{~g}$ and
Table 1. Stocking details in various treatments/Ponds with species ratio and density.

\begin{tabular}{lll}
\hline Treatment & Combination & $\begin{array}{l}\text { Stocking Density } \\
\left(\text { Fish } / \mathbf{m}^{3}\right)\end{array}$ \\
\hline T1 & $40: 30: 30$ & 3 \\
T2 & $40: 30: 30$ & 5 \\
T3 & $30: 40: 30$ & 3 \\
T4 & $30: 40: 30$ & 5 \\
T5 & $30: 30: 40$ & 3 \\
T6 & $30: 30: 40$ & 5 \\
C (Control) & $25: 25: 50$ & 10 \\
\hline
\end{tabular}

$1.19 \mathrm{~g}$ of silver carp, grass carp and common carp, respectively were stocked in the control unit. Over all better growth of all tested 3 exotic fish species was observed in the low stocking density i.e. $3 \mathrm{fish} / \mathrm{m}^{3}$ over the stocking density of $5 \mathrm{fish} / \mathrm{m}^{3}$ and $10 \mathrm{fish} / \mathrm{m}^{3}$ in the control. The net production was $12.6 \%$ higher with stocking density of 3 fish $/ \mathrm{m}^{3}$. Among the both tested density, the combination of 30: 40: 30 was superior in terms of growth and production in comparison to the other combinations. It was $4 \%$ higher over the other tested combinations with stocking density of $3 \mathrm{fish} / \mathrm{m}^{3}$ and $6.5 \%$ higher with stocking density of $5 \mathrm{fish} / \mathrm{m}^{3}$. The best combination of species i.e. 30 : 40 : 30 was $45.6 \%$ better over the control in terms of growth and production. In cold water conditions of mid hills, the growth of exotic carps in 10 months was recorded in the avg. weight range of $200-310 \mathrm{~g}$ with stocking density of 3 fish $/ \mathrm{m} 3$. The maximum growth was recorded for grass carp followed by common carp and silver carp. In control unit it was $50 \mathrm{~g}, 60 \mathrm{~g}$ and $55 \mathrm{~g}$ for the silver carp, grass carp and common carp, respectively. The growth in control unit was significantly very low in comparison of experimental units; it may be due to high stocking density and improper species combination (Table 3). In different studies at plain area, Jena et al., (2001) reported the superior growth of silver carp over the other exotic and indigenous carps in polyculture system. But, in hilly climate the growth of silver carp was not in higher side probably due to the low production of phytoplankton. Survival rate in different experiment was found to be $74 \%, 79 \%$ and $83 \%$ with stocking density of $3 \mathrm{fish} / \mathrm{m}^{3}$ and $70 \%, 74 \%$ and $75 \%$ with stocking density of $5 \mathrm{fish} / \mathrm{m}^{3}$ and $50 \%, 52 \%$ and $56 \%$ in control for the silver carp, grass carp and common carp, respectively. Priyadarshini et al., (2011) obtained survival rate of Cyprinus carpio fry $52.12 \%$ in manure applied pond and this supports our present findings also and the present data reflected that the survival were minimum for the surface feeder fish followed by column feeder and highest for bottom feeder. The survival was found better in low stocking density in comparison to higher stocking density. Apart from this it was observed that high percentage of survival can be achieved with healthy fish, predator free pond, favourable ecological conditions etc. Many abiotic and biotic components of aquatic ecosystem directly and indirectly influence water quality. Measurements of these components also reflect the dynamics of the liv- 
ing organisms such as metabolic and physiological behaviour of aquatic ecosystems. $\mathrm{pH}$, temperature and dissolved oxygen have great influence on fish growth (Ahmad et al., 2008; Noor et al., 2010) and in our present findings impact of biotic and abiotic components also reflects its impact on the production level irrespective of any species combination and stocking density. The area under study belongs to cold climatic conditions and reduce temperature has its impact on fish growth which was well supported by the findings of Hussain et al., (2011) decrease in water temperature also reduces fish growth. At the end of month of August, fishes measured between $300-425 \mathrm{~g}$ in 8 month period. Average growth rate of fish at time of final harvesting i.e. November-December ranged in between 340-490 g., with the maximum average growth of common carp (490 g.) followed by grass carp (415 g.) and silver carp (340 g.). Singh et al., 2008 reported fish production of $45-50 \mathrm{~kg} / 100 \mathrm{~m}^{3} /$ year in district Champawat supporting our findings of production range and this might be due to comparable adaptive environmental conditions and species. In the upland waters the Indian major carps do not grow well, due to the low thermal regime. Therefore, Chinese carps were taken as the candidate species for polyculture. The present data revealed that there is more influence of stocking density than the species combination on the production level. Better production at stocking combination of 30:40:30 in present study is well supported by the findings of Ahmad et al., 2013 stating a stocking ratio of 1: 1.5 gives better results in terms of growth and survival in polyculture. Higher the stocking density lowers the production level. The production level of existing practice of the farmers may be enhanced up to 1.5 times with proper stocking density i.e. $3 \mathrm{fish} / \mathrm{m}^{3}$ and perfect species combination i.e. 30: 40: 30 for silver carp, grass carp and common carp, respectively. Krishna (2005) reported $4360 \mathrm{~kg} / \mathrm{ha} / \mathrm{yr}$., $5900 \mathrm{~kg} / \mathrm{ha} / \mathrm{yr}$., and $6600 \mathrm{~kg} / \mathrm{ha} / \mathrm{yr}$. production with three Indian major carp species culture. According to Abbas et al., (2010) C. catla showed maximum growth followed by L. rohita in decreasing order while $C$. carpio showed the lowest body weight in poly-culture system and the similar sort of results was also obtained in our findings. Sometimes negative effects of high stocking density on fish growth and survival can be caused by deterioration of water quality, causing the increment of fish metabolites and carbon dioxide with reduction of $\mathrm{pH}$ level system (Ruyeta et al., 2007; Hosfeld et al., 2009) and this might be the reason associated with low production of exotic fishes at stocking density of $5 / \mathrm{m}^{3}$ in the present study.

Accordingly from the production performance of fishes, it may be recommended that farmers of mid hills region may adopt polyculture of exotic carps with stocking density of $3 \mathrm{fish} / \mathrm{m}^{3}$ in $30 \%$ silver carps, $40 \%$ grass carps and $30 \%$ common carps combination (Table 3). Therefore, the production cycle of exotic 


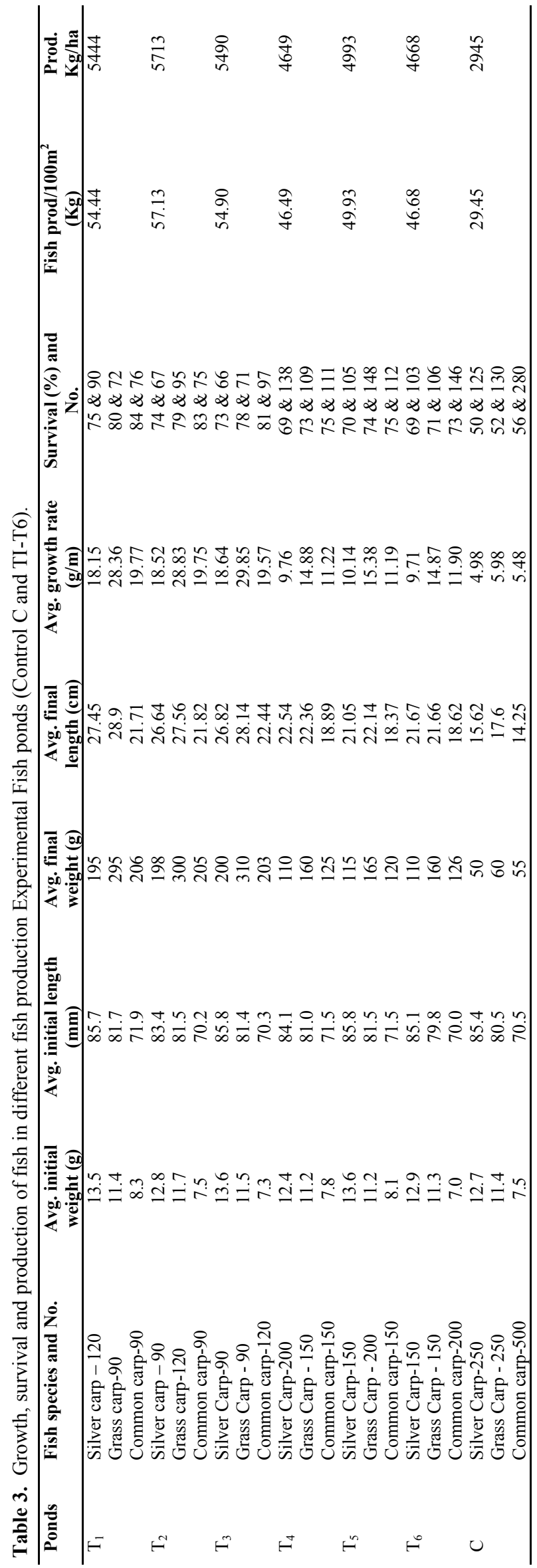

carp culture in mid hill conditions may be designed for stocking density of $3 \mathrm{fish} / \mathrm{m}^{3}$ to fetch good market price and income.

\section{Conclusion}

The present study clearly suggested that among the both tested density i.e. 40:30:30 and 30:40:30, the combination of 30: 40: 30 was superior in terms of growth and production. It was $4 \%$ higher over the other tested combinations with stocking density of 3 fish $/ \mathrm{m}^{3}$ and $6.5 \%$ higher with stocking density of 5 fish/ $\mathrm{m}^{3}$. Survival rate in different experiment was found to be $74 \%, 79 \%$ and $83 \%$ with stocking density of 3 fish/ $\mathrm{m}^{3}$ and $70 \%, 74 \%$ and $75 \%$ with stocking density of 5 fish $/ \mathrm{m}^{3}$ and $50 \%, 52 \%$ and $56 \%$ in control for the silver carp, grass carp and common carp, respectively. Survival rate was found to be lower in stocking density of $3 \mathrm{fish} / \mathrm{m}^{3}$ as compared with stocking density of 5 fish $/ \mathrm{m}^{3}$ for the silver carp, grass carp and common carp respectively. In cold water conditions of mid hills, the growth of exotic carps in 10 months was recorded in the avg. weight range of $200-310 \mathrm{~g}$ with stocking density of $3 \mathrm{fish} / \mathrm{m}^{3}$. In control unit it was $50 \mathrm{~g}, 60 \mathrm{~g}$ and $55 \mathrm{~g}$ for the silver carp, grass carp and common carp respectively. The maximum growth was recorded for grass carp followed by common carp and silver carp in both the densities and combinations. The growth in control unit was significantly very low in comparison to other experimental units and this might be due to high stocking density and improper species combination. The production level of existing practice of the farmers may be enhanced up to 1.5 times with proper stocking density i.e. $3 \mathrm{fish} / \mathrm{m}^{3}$ and perfect species combination i.e. 30: 40: 30 for silver carp, grass carp and common carp, respectively. Hence from the production performance of fishes, it is recommended that farmers of mid hills region may adopt polyculture of exotic carps with stocking density of $3 \mathrm{fish} / \mathrm{m}^{3}$ in $30 \%$ silver carps, $40 \%$ grass carps and $30 \%$ common carps combination.

\section{REFERENCES}

Abbas, S., Ahmed, I., Salim, M. and Rehman, K. (2010). Comparative effects of fertilization and supplementary feed on growth performance of three fish species. Int. J. Agric. Biol., 12: 276-280

Ahmad, M., Abbas, S., Javid, A., Ashraf, M., Iqbal, Azmat, H., Khan, T., Mahmood, S. and Haider, R. (2013). Effect of varying stocking density of bottom feeder fish Cirrhinus mrigala and Cyprinus carpio on growth performance and fish yield in polyculture system. Int. $J$. Fish. Aquac. 5(11): 278-285.

Ahmad, N., Ahmed, I., Saleem, M. and Ashraf, M. (2008). Effect of different levels of mineral phosphorus with and without nitrogen on the dry weight of planktonic biomass, increase in fish production and biomass conversion efficiencies. Pak. J. Agric. Sci. 45:122-128.

Alyshbaev, A. (2013). Feeding level effect on the growth of rainbow trout (Onchorynchus mykiss) fingerlings. MS Thesis. Department of Biology, University of Eastern 
Finland. pp. 40.

Bhatt, J.P. Kumar, M., Pandit, M.K. (2012). Elevational gradients in fish diversity in the Himalaya: water discharge is the key driver of distribution patterns. PLOS ONE, 7 (9):e46237.

Chandrasekharan, V.S., Bisht, H.C.S. and Singh, U.P. (2005). Effect of feeding frequency on the growth of the fresh water prawn. Indian J. of Fish, 52 (1): 111-113.

Hassan, A.A.R. (2011). Zooplankton as natural live food for three different fish species under concrete ponds with mono-and polyculture conditions. Egyptian J. Aquac. $1: 1$.

Hosfeld, C.D., Hammer, J., Handeland, S.O., Fivelstad, S., and Stefansson, S.O. (2009). Effects of fish density on growth and smoltification in intensive production of Atlantic salmon (Salmo salar L.). Aquaculture 294(34):236-241

Hussain, M., Hussain, S.M., Afzal, M., Raza, S.A., Hussain, N. and Mubarik, M.S. (2011). Comparative study of replacement of maize gluten with rice bran (3:1 and 1:3) feed supplement: effect on fish growth in composite culture. Pak. J. Agric. Sci. 48(4):321-326.

Jena, J. K., Ayyappan, S., Aravindakshan, P. K. and Muduli, M. K. (2001). Comparative evaluation of growth, survival and production of carp species at different stocking densities under polyculture. Indian J. Fish, 48 (1):17 -25 .

Jena, J.K. and Gopalakrishnan, G. (2012). Aquatic biodiversity management in India. Proceedings of the National Academy of Sciences, India Section B: Biological Sciences, 82: 363-379.

Kefi, A.S., Chung, U.P., Mupenda, N. and Mumba, C. (2014). Is Fortification of Methionine Necessary in Soya Bean (Glycine max) Based Feeds for Oreochromis andersonii (Castelnau, 1861) Raised in Semi - Concrete Ponds? Journal of Marine Science: Research \& Development 4: 154. DOI: 10.4172/2155-9910.1000154.

Krishna, P.V. (2005). Management and economics of commercial fresh water fish farming in Gudla Valleru, Krishna district Andhra Pradesh. Aquacult. 6 (1) 81-87.

Mahanta, P.C. and Ayyappan, S. (2007). Coldwater fish resources and rehabilitation. In.: Proceeding of national workshop on parvtiya matisyaki paridrasya, vikas, pra- bandhan avam anusandhan. NRCCWF, Bhimtal. 3-6.

Mahanta, P.C., Sarma, D. ( 2010). Coldwater Fisheries Management. DCFR, ICAR, Bhimtal - 263 136, Distt. Nainital (Uttarakhand), India. P. 1-451.

Noor EL, Deen AIE, and Mona, S.Z. (2010). Impact of climatic changes (oxygen and temperature) on growth and survival rate of Nile tilapia (Oreochromis niloticus). Rep. Opin. 2:192-195.

Priyadarshini, M., Manissery, J.K., Gangadhara, B. and Keshavanath, P. (2011). Influence of feed, manure and their combination on the growth of Cyprinus carpio (L.) fry and fingerlings. Turk J Fish Aquat Sci. 11:577- 586.

Ruyeta JP-L, Bayon, N.L and Gros, S. (2007). How to assess fin damage in rainbow trout,Oncorhynchus mykiss? Aquat Living Resour 20:191-195

Singh, H.R. (2007). Hill fisheries development and conservation in Uttarakhand. In: proceeding of national workshop on parvtiya matisyaki paridrasya, vikas, prabandhan avam anusandhan. NRCCWF, Bhimtal, April 6-7, 2007. 25-29.

Singh, V.K. and Mehta, K.S. (2008). Annual report on the progress of fisheries research project. From 1st Sept.2007 to 31st Aug. 2008.

Singh, A.K., Kumar, Prem and Ali, S. (2014). Ichthyofaunal Diversity of the Ganges River System in Central Himalayas, India: Conservation Status and Priorities. In: Sinha, R.K. and Ahmed, B. (eds.) Rivers for Life - Proceedings of the International Symposium on River Biodiversity: Ganges-Brahmaputra-Meghna River System, Ecosystems for Life, A Bangladesh-India Initiative, IUCN, International Union for Conservation of Nature, pp. 208-214. ISBN:978-93-5196-807-8.

Tripathi, S.D. (2007). Development and management of Coldwater fisheries in India. In: Proceeding of national workshop on parvtiya matisyaki paridrasya, vikas, prabandhan avam anusandhan. NRCCWF, Bhimtal. 3031.

Tyagi, B.C. and Joshi, K.D. (2009). Innovation and adoption of Chinese carp culture in Indian himalayan region: A success story. National symposium on coldwater fisheries management: New strategies and approaches. Souvenir cum Abstract book. DCFR, Bhimtal, 2-4 October, $122-123$. 